\title{
Carbon Stock Estimation Along Altitudinal Gradient in Sekele-Mariam Dry Evergreen Montane Forest, North-Western Ethiopia
}

\author{
Asersie Mekonnen ${ }^{1,}$, , Motuma Tolera ${ }^{2}$ \\ ${ }^{1}$ Forest and Rangeland Plants Biodiversity Directorate, Ethiopian Biodiversity Institute, Addis Ababa, Ethiopia \\ ${ }^{2}$ Wondo Gent College of Forestry and Natural Resource, Shashemene, Ethiopia
}

Email address:

asersmekonnen $a$ gmail.com (A. Mekonnen), motumatolera@gmail.com (M. Tolera)

${ }^{*}$ Corresponding author

\section{To cite this article:}

Asersie Mekonnen, Motuma Tolera. Carbon Stock Estimation Along Altitudinal Gradient in Sekele-Mariam Dry Evergreen Montane Forest, North-Western Ethiopia. Agriculture, Forestry and Fisheries. Vol. 8, No. 2, 2019, pp. 48-53. doi: 10.11648/j.aff.20190802.14

Received: March 22, 2019; Accepted: April 23, 2019; Published: June 12, 2019

\begin{abstract}
This study was conducted to estimate carbon stock along altitudinal gradient of Sekele-Mariam dry Afromontane forest, North- Western Ethiopia. A systematic random sampling was employed to collect tree/shrub diameter and height, litter and soil data. A total of 60 plots with $50 \mathrm{~m} * 50 \mathrm{~m}$ size each with nested plot $(1 \mathrm{~m} * 1 \mathrm{~m})$ size for litter and soil were laid on the transect line. Diameter at breast height (DBH) of trees/shrubs with $\mathrm{DBH} \geq 5 \mathrm{~cm}$ and height were measured. Carbon stock was estimated using allometric equation and soil organic carbon was analyzed in the laboratory following Walkley Black method. The result of this study revealed that Sekele-Mariam forest had stored a total of 185.71 ton carbon/ha within its aboveground, belowground, litter biomasses and soil. The higher carbon stock in all carbon pools was found at the higher altitudinal range (2395-2460 m a.s.l.). Analysis of variance (ANOVA) result indicated that carbon stock between altitudinal gradient was not significant. The study area had smaller stock of carbon in its biomass and therefore, better forest conservation and management are the best strategy to enhance the carbon stock of the study area.
\end{abstract}

Keywords: Biomass, Carbon Sequestration, Climate Change, Soil Organic Carbon, Sekele-Mariam Forest

\section{Introduction}

Forests sequester and store more carbon than any other terrestrial ecosystem and are an important natural 'brake' on climate change [14]. The biomass and carbon stocks in forests are important indicators of forests' productive capacities, energy potential, and capacity to sequester carbon. The role of forests as terrestrial sinks and source of $\mathrm{CO}_{2}$ has received increasing attention since the adoption of the 1997 Kyoto Protocol to the United Nation Framework Convention on Climate Change [11]. The world's forests store $289 \mathrm{Gt}$ of carbon on their biomass [10]. However, carbon stock in forest biomass decreased by an estimated $0.5 \mathrm{Gt}$ annually during the period 2005-2010 globally, due to forest cover change [10]. The carbon stored in the aboveground living biomass of trees is typically the largest carbon pool and is directly influenced by deforestation and forest degradation [16]. Ethiopia has one of the largest forest resources in the horn of Africa [22]. The country's Forest resources supply most of the wood products used with in the country, as well as a large volume of diverse non-timber forest product [21]. The forest resources play significant roles in the livelihoods of the community and the national economy at large. Their direct roles include provisions of energy, construction wood, poles, timber and non-timber forest products (NTFPs) that are highly prized for their food, medicinal and commercial values [1]. Moreover, forests play a vital role in climate change mitigation through sequestering carbon dioxide from the atmosphere. Ethiopia's forest resources have store 219 million ton of carbon in their living biomass [10]. Despite their economic and environmental value, the countries' forests resources are under threat. Deforestation and forest degradation activities are the main sources of forest carbon stock loss and GHGs emission. According to [7], 37\% of the total greenhouse gas emission in the country comes from forestry due to anthropogenic activities (deforestation and 
forest degradation). Currently the country is implementing a robust system for monitoring and measuring carbon emissions and removals to enable the country to report and verify actions on deforestation and forest degradation and other activities aiming to conserve, sustainably manage and increase forest carbon stocks [23].

Forest carbon stock is highly variable due to various factors and processes operating in the systems. Forest carbon stock is affected by different environmental factors such as: altitude, aspect and slope by affecting the distribution of tree species [12]. Dry Afromontane forest stores a huge amount of aboveground carbon compared to other terrestrial ecosystems in Ethiopia [18]. Despite their immense carbon sequestration potential most forests of the country lacks carbon stock data/ information. Nowadays, estimates of carbon stock in forests is critical in carbon credit programs- quantities of assimilated carbon claimed against $\mathrm{CO}_{2}$ emission. Sekele-Mariam forest is one of the dry Afromontane forest in West Gojjam Zone North-Western Ethiopia and its carbon stock potential is not studied yet. Altitude is one of the key environmental factor that had significant impact on carbon pools (aboveground, belowground, litter and soil) [15].

\section{Materials and Methods}

\subsection{Description of the Study Area}

Sekele-Mariam forest is located in Dembecha district, West Gojjam Zone of Amhara National Regional State, Ethiopia at about $350 \mathrm{~km}$ north of Addis Ababa. The forest lies between $10^{\circ} 35^{\prime}-10^{\circ} 37^{\prime} \mathrm{N}$ latitudes and $37^{\circ} 28^{\prime}-37^{\circ} 30 \mathrm{E}$ longitudes. The forest covers an area of 532.42 hectare. Sekele-Mariam forest is characterized by rugged terrain with an altitude ranges from $2259 \mathrm{~m}$ to $2460 \mathrm{~m}$ a.s.l. The study area is categorized under mid highlands locally known as "'Weyna Dega" agro-climatic zone. The mean minimum and maximum temperature of the study area were $8.5^{\circ} \mathrm{C}$ and $29^{\circ} \mathrm{C}$ respectively and had an average temperature of $18.5^{\circ} \mathrm{C}$. The average annual rainfall was $1368 \mathrm{~mm}$ and had unimodal rainfall distribution [9]. Sekele-Mariam forest is categorized under dry evergreen montane forest of vegetation classification of Ethiopia [29] and is characterized by Croton, macrostachyus Albizia gummifera, Calpurnia aurea, Acacia abyssinica, Maytenus obscura Buddleia polystachy, Bersama abyssinica, Carissa spinarum, Nuxia congesta, Acacia lahai, Clausena anisata, Rosa abysinica, Grewia ferruginea, Vernonia auriculifera, Pavetta abyssinica among others.

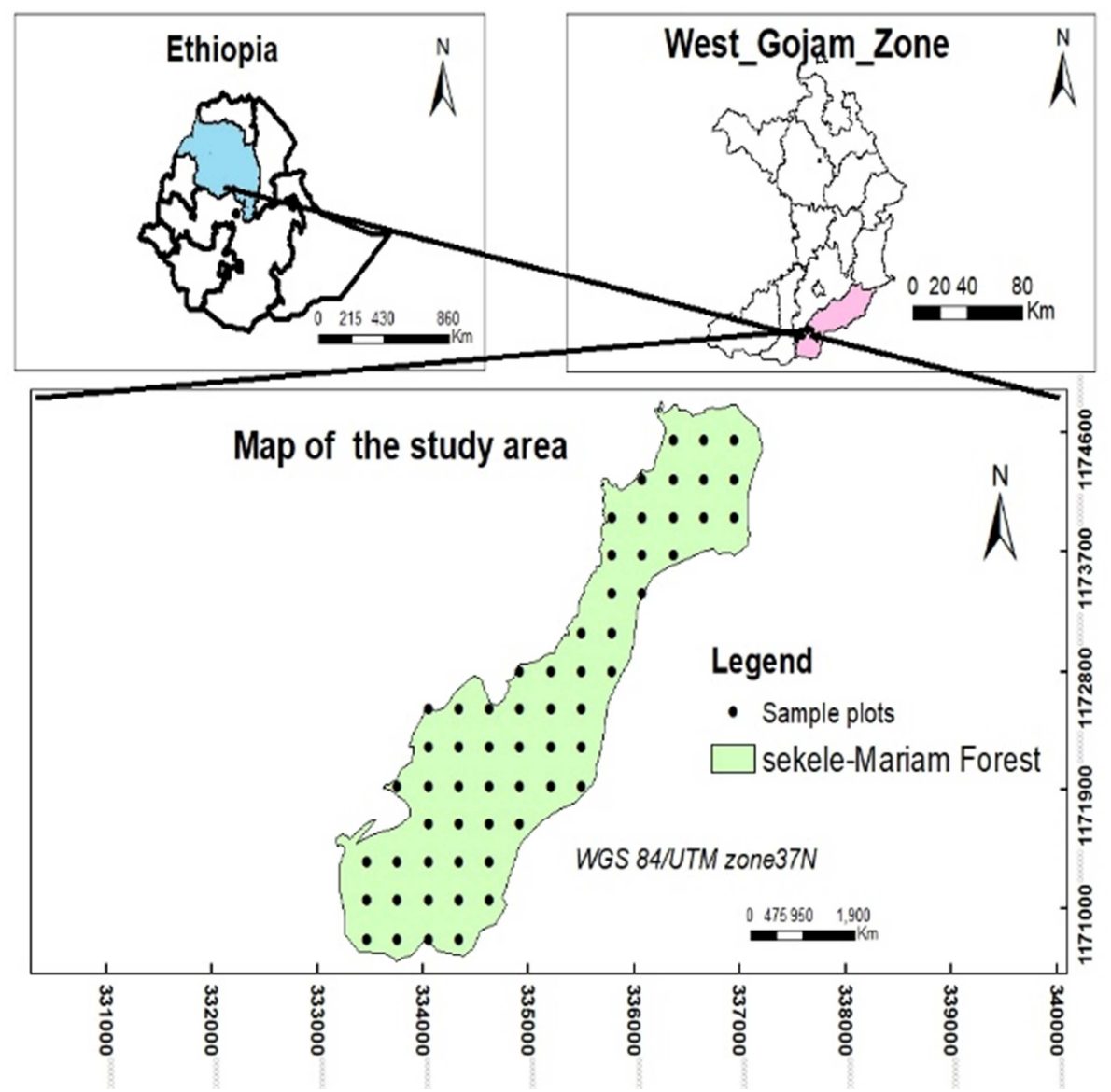

Figure 1. Map of Ethiopia showing West Gojjam Zone and the study area (Sekele-Mariam forest).

\subsection{Sampling design and techniques}

The spatial boundaries of the study area were defined and geographic coordinates and elevation of the strata were taken using Geographical Positioning System (GPS) to generate the map of the study area. with the aid of GIS software (Q 2.2GIS). Considering the topography of the forest the study area was stratified in to three different strata based on altitudinal 
variation as; lower altitude (2259-2326) considered as dry Weyna Dega; middle altitude (2327-2394) and higher altitude (2395-2460) a.s.l which is considered as wet Weyna Dega agro-climatic zone.

The number of plots to be measured were determined using pragmatic approach [28] and therefore, a total of 60 sample plots were sampled. Systematic transect sampling was employed and thus, four transect lines were laid with an interval of $200 \mathrm{~m}$ between each transect line and square sample plots with an area of $2500 \mathrm{~m}^{2}(50 \mathrm{~m} * 50 \mathrm{~m})$ each was designed along transect lines with $300 \mathrm{~m}$ gaps between each plots. Within the large plot $(50 \mathrm{~m} * 50 \mathrm{~m})$ dendrometric parameters was measured. Moreover, nested plot of $1 \mathrm{~m} * 1 \mathrm{~m}$ subplot for litter and soil sample were taken [3, 2].

\subsection{Data Collection Methods}

In each plot trees with $\geq 5 \mathrm{~cm}$ DBH were measured at 1.3 $\mathrm{m}$ above the ground since in carbon stock measurement the minimum diameter is often $5 \mathrm{~cm}$ DBH as recommended by $[17,25]$. For inclined terrain DBH tree measurement at $1.3 \mathrm{~m}$ was taken on uphill position. The DBH of trees/shrubs were measured using caliper and range finder was used for height measurement. Woody species with their vernacular name of the study was recorded in the species checklist.

\subsection{Field Carbon Stock Measurement}

\subsubsection{Above and Below Ground Biomass}

The DBH (at $1.3 \mathrm{~m}$ ) of each trees and shrubs with $\geq 5 \mathrm{~cm}$ diameter in each sample plot was measured using caliper and rangefinder was used for height measurement. The biomass was calculated using allometric equations developed by [5] shown below:

$$
\mathrm{AGB}=0.0673 *\left(\mathrm{WD}^{*} \mathrm{DBH}^{\wedge} 2 * \mathrm{Ht}\right){ }^{\wedge} 0.976
$$

Where, AGB = Aboveground biomass $(\mathrm{Kg})$; WD = Wood density $\left(\mathrm{g} / \mathrm{cm}^{3}\right) ; \mathrm{DBH}=$ diameter at breast height $(\mathrm{cm}) ; \mathrm{Ht}=$ Total height of the tree $(\mathrm{m})$

Belowground biomass was estimated using IPCC root -toshoot ratio value of 0.26 for tropical dry forests [17] i.e.:

$$
\mathrm{BGB}=\mathrm{AGB} \times 0.26
$$

Where, BGB is belowground biomass $(\mathrm{Kg}), \mathrm{AGB}$ is aboveground biomass, 0.26 is conversion factor

The biomass was converted to units of carbon stock by multiplying by a carbon fraction of 0.47 and 3.67 respectively [17].

\subsubsection{Litter Biomass}

According to [24], estimation of the amount of biomass in the litter is calculated as:

$$
L B=\frac{\text { Wfield }}{A} *\left(\frac{\text { Wsubsampledry }}{\text { Wsubsamplefresh }}\right) * \frac{1}{10000}
$$

Where: LB $=$ Litter (biomass of litter ton/ha)
$\mathrm{W}$ field = weight of wet field sample of litter sampled within an area of size $1 \mathrm{~m}^{2}(\mathrm{~g})$;

$\mathrm{A}=$ size of the area in which litter collected (ha);

$\mathrm{W}$ (sub, fresh) = weight of the fresh sub-sample of litter taken to the laboratory to determine moisture content.

$\mathrm{W}($ subsample $d r y)=$ weight of the oven-dry sub-sample of litter taken to the laboratory to determine moisture content $(\mathrm{g})$.

The total carbon content of litter (ton/ha) =Total dry litter biomass*Carbon fraction; mathematically;

$$
\mathrm{C}_{\mathrm{T}}=\mathrm{LB} \times \% \mathrm{C}
$$

Where, $\mathrm{C}_{\mathrm{T}}$ is total carbon stocks in the dead litter in ton/ ha, $\% \mathrm{C}$ is carbon fraction determined in the laboratory [24].

\subsubsection{Soil Organic Carbon}

Soil organic carbon was determined in the laboratory following Walkley-Black Method. In the laboratory, soil samples were dried at $105^{\circ} \mathrm{C}$ for 24 hours to remove the soil moisture and to determine the percentage of organic carbon as well as the bulk density [24]. According to [24], the soil organic carbon was calculated from the bulk density and volume of the soil as follows:

$$
\mathrm{BD}=\frac{\mathrm{wdry}}{\mathrm{V}}
$$

Where,

$\mathrm{BD}=$ bulk density $\left(\mathrm{g} / \mathrm{cm}^{3}\right)$ of the soil sample,

Wdry = air dry weight ( $\mathrm{g}$ ) of soil sample,

$\mathrm{V}=$ volume $\left(\mathrm{cm}^{3}\right)$ of the soil sample

The volume of each soil sample in turn was calculated as;

$$
\mathrm{V}=\mathrm{h} * \pi r^{2}
$$

Where,

$\mathrm{V}=$ volume of the soil in the core sampler augur in $\mathrm{cm}^{3}$,

$\mathrm{h}=$ the height of core sampler augur in $\mathrm{cm}$, and

$\mathrm{r}=$ the radius of core sampler in $\mathrm{cm}$.

Then, soil organic carbon was calculated as follows:

$$
\mathrm{SOC}=\mathrm{BD} * \mathrm{D} * \% \mathrm{C}
$$

Where,

$\mathrm{SOC}=$ soil organic carbon stock per unit area (ton/ ha), $\mathrm{BD}=$ soil bulk density $\left(\mathrm{g} / \mathrm{cm}^{3}\right)$,

$\mathrm{D}=$ the total depth at which the sample was taken $(40 \mathrm{~cm}$ i.e. $0-20 \mathrm{~cm}$ and $20-40 \mathrm{~cm}$ ) and

$\% \mathrm{C}=$ Carbon concentration $(\%)$

\subsection{Total Carbon Stock}

The total carbon stock density was calculated by adding the carbon stock densities of the individual carbon pools using [24] formula as follows;

$\mathrm{C}_{\mathrm{T}}=\mathrm{AGC}+\mathrm{BGC}+\mathrm{CL}+\mathrm{SOC}(8)$

Where,

$\mathrm{C}_{\mathrm{T}}=$ Carbon stock density for all pools (ton/ ha),

$\mathrm{AGC}=$ Carbon in above -ground tree biomass (ton $\mathrm{C} / \mathrm{ha}$ ),

$\mathrm{BGC}=$ Carbon in below-ground biomass (ton $\mathrm{C} / \mathrm{ha}$ )

$\mathrm{CL}=$ Carbon in dead litter (ton $\mathrm{C} / \mathrm{ha}$ ) and 
$\mathrm{SOC}=$ Soil organic carbon (ton $\mathrm{C} / \mathrm{ha})$.

\subsection{Data Analysis}

The data analysis of various carbon pools measured $(\mathrm{DBH}$, fresh weight and dry weight of litter and soil) was done in Statistical Package for Social Science (SPSS) software version 23, Analysis of Variance (ANOVA) was used to test the relationship between carbon stocks with altitude at 95\% confidence interval.

\section{Results}

\subsection{Carbon Stock in Different Carbon Pools}

As depicted in (Table 1), the soil component shares the highest carbon stock followed by aboveground carbon of the total forest carbon stock, whereas the belowground and litter contributed the lowest carbon stock.

Table 1. Mean carbon stock of the different carbon pools in Sekele-Mariam forest (60 plots).

\begin{tabular}{|c|c|c|c|c|c|}
\hline & \multicolumn{5}{|c|}{ Carbon Pools } \\
\hline & AGC & BGC & LC & SOC & Total \\
\hline Mean (ton/ha) & 37.54 & 9.76 & 0.02 & 138.39 & 185.71 \\
\hline Percentage $(\%)$ & 20.21 & 5.26 & 0.01 & 74.52 & 100 \\
\hline
\end{tabular}

Table 2. Comparison of carbon stock (ton/ha) of Sekele-Mariam forest with other similar forest type in Ethiopia.

\begin{tabular}{lllllll}
\hline Study areas & AGC & BGC & LC & SOC & Total & References \\
\hline Sekele-Mariam forest & 37.54 & 9.76 & 0.02 & 138.39 & 185.71 & Current study area \\
Humbo forest & 30.77 & 14.46 & 12.54 & 168.20 & 225.97 & Chinasho et al., 2015 \\
Zequala Monastery forest & 237.20 & 47.60 & 6.99 & 57.62 & 349.41 & Girma et al., 2014 \\
Tara Gedam forest & 306.37 & 61.52 & 0.90 & 274.32 & 643.11 & Gedefaw et al., 2014 \\
Meskel Gedam forest & 146.34 & 29.27 & 3.03 & 131.79 & 310.43 & Dagnachew Tefera, 2016 \\
Egdu forest & 278.08 & 55.62 & 3.47 & 277.56 & Feyissa et al., 2013 \\
\hline
\end{tabular}

\subsection{Carbon Stock Along Altitudinal Gradient in Carbon Pools}

There was distinct variation of mean carbon stock in each carbon pools with different altitudinal ranges but, the variation of each carbon pools (AGC, BGC, LC, SOC) is statistically insignificant at 95\% confidence interval (Table 3).

Table 3. Mean carbon stock (ton/ha) along altitudinal gradient of Sekele-Mariam forest.

\begin{tabular}{lllll}
\hline Altitude class & AGC & BGC & LC & SOC \\
\hline Lower & 34.73 & 9.02 & 0.01 & 0.01 \\
Middle & 28.96 & 7.52 & 0.02 & 128.29 \\
Higher & 42.40 & 11.02 & 3.233 & 149.35 \\
F value & 1.487 & 1.487 & 0.047 & 137.28 \\
P value & 0.235 & 0.235 & 1.049 & 0.364 \\
\hline
\end{tabular}

\section{Discussion}

The mean aboveground carbon stock of Sekele-Mariam forest was smaller as compared to previously studied similar forest type of Ethiopia except Humbo forest. The variation of carbon in the aboveground biomass may be due to intensive forest degradation mainly fuel-wood collection. Moreover, stand structure and composition, topography, altitude and micro climate variation may have also contributed for the variation of carbon in the aboveground biomass. Besides, variation in tree dendrological parameters measured, allometric equations applied, carbon fraction used and rootshoot ratio used to estimate below ground biomass may also have resulted in the discrepancy of estimation of aboveground and belowground biomass and carbon stock. In line with allomertic equation most researchers used [4] equation to estimate forest carbon stock in Ethiopia. Moreover, they used a carbon fraction of 0.5 suggested in the IPCC 2003 Good Practice Guidance. The different types of models used for biomass estimation have impact on the value of carbon estimated in a given forest [21].
The mean carbon stock in litter pool of the current study was 0.02 ton/ha which is lower than other similar forest type indicated in (Table 2). The amount of litter fall and its carbon stock of the forest can be influenced by the forest vegetation (species, age and density), climate and relatively fast decomposition rate in the tropics [13]. The reason for smaller litter carbon may be due to fast decomposition rate and less amount of litter fall in the study area.

As reported in Luke [20], the average soil organic carbon in Ethiopia ranges from 94 to 133 ton/ha which is smaller compared to the present study and the IPCC default values (31 to 130 ton/ha) for different tropical soils [17]. In this study, the soil carbon pool had the highest carbon stock compared to other pools in the study area. Soil is the largest carbon pools in global terrestrial ecosystems, because they can contain three times more carbon than that contained in vegetation [27], The mean carbon stock of soil organic pool in the study area was lower as compared with other studies except Zequala forest and Meskel Gedam forest (Table 2). This could be due to the existence of low soil organic matter, the accumulation of soil organic carbon depends on the quantity of litter [19] and root activity such as rhizo- 
deposition and decomposition [26].

The highest total carbon stock was recorded in the higher altitudinal range whereas smaller carbon stock was recorded in lower altitudinal range. The carbon stock in all carbon pools of the study area varied with altitudinal ranges. but did not show direct increment or decrement. This study showed that the mean carbon stock in all carbon pools exhibits an increasing trend with increasing altitudinal variation, the reason for this may be due to, disturbance level and species composition and density occurred in the altitudinal ranges. As noted from field observation, more wood collection for construction and fuel wood was highly pronounced in lower altitude than the higher one. Overall, the carbon pool of Sekele-Mariam forest did not show significant variation along altitudinal gradient as aboveground carbon, belowground carbon, litter carbon and soil organic carbon. Similar finding was reported from [6]. The reason for such statistically insignificant result in the carbon pools may be due to the similar species composition and soil type throughout the altitudinal gradient of the forest.

\section{Conclusion}

Sekele-Mariam. forest had stored a total of 185.71 ton $\mathrm{C} /$ ha in its biomass. The largest carbon stock was found in the soil organic carbon followed by the aboveground biomass The carbon stock of the study area was smaller compared to other studies of similar forest type in Ethiopia. Carbon stock in different carbon pools (aboveground and belowground biomass, litter biomass and soil) has a potential to decrease the rate of improvement of atmospheric concentration of carbon dioxide. Increase in carbon stock in Dry Afromontane forest can be achieved through sustainable forest management and enrichment planting. Furthermore, attention has to be given on the conservation of the Dry Afromontane forest to enhance the carbon sequestration capacity so as to mitigate climate change. Carbon stock in all carbon pools was varied with altitude. but, the variation was not statistically significant at $95 \%$ confidence interval.

\section{Acknowledgements}

We would like to thanks to MRV Project through Hawassa University, Wondo Genet College of Forestry and Natural Resources for financing this study. Sincere thanks also goes to Mr. Addisu Abay and Mr. Getasew Shibeshi for their unreserved assistance in field data collection.

\section{References}

[1] Asfaw, Z., Mulatu, Y., Assefa, B., Abebe, T., Duna, S., Mulugeta, G., Berhanten, H. and Kassa, H. (2015) Enhancing the Role of Forestry in Building Climate Resilient Green Economy in Ethiopia: Strategy for scalling up effective forest management practices in Southern Nations, Nationalities and Peoples Regional State with particular an emphasis on agroforestry.

[2] Assaye, H. (2014) Determination of Conservation Benefits and Carbon Sequestration Capacity of the Awash National Park Ethiopia, Addis Ababa, Ethiopia.

[3] Bhishma P., Subedi, Pandey, S. S., Pandey, A., Rana, E. B., Bhattarai, S., Banskota, T. R., Charmakar, S. and Tamrakar, R. (2010) Forest Carbon Stock Measurement: Guidelines for measuring carbon stocks in community-managed forests. Asia Network for Sustainable Agriculture and Bioresources, Federation of Community Forest Users, International Centre for Integrated Mountain Development, Katmandú, Nepal. 69p.

[4] Brown, S., Gillespie, A. J. and Lugo, A. E. (1989) Biomass estimation methods for tropical forests with applications to forest inventory data. Forest science, 35 (4), pp. 881-902.

[5] Chave, J., Réjou - Méchain, M., Búrquez, A., Chidumayo, E., Colgan, M. S., Delitti, W. B., Duque, A., Eid, T., Fearnside, P. M., Goodman, R. C. and Henry, M. (2014) Improved allometric models to estimate the aboveground biomass of tropical trees. Global change biology, 20 (10), pp. 3177-3190.

[6] Chinasho, A., Soromessa, T. and Bayable, E. (2015) Carbon stock in woody plants of Humbo forest and its variation along altitudinal gradients: The case of Humbo district, Wolaita zone, southern Ethiopia. International Journal of Environmental Protection and Policy, 3 (4), pp. 97-103.

[7] C. R. G. E. (2011) Ethiopia's Climate-Resilient Green Economy, Green Economy Strategy. Addis Ababa: FDRE.

[8] Dagnachew Tefera. (2016) Carbon Stock of Meskele Gedam Forest and its Contribution to Climate Change Mitigation. M.Sc. Thesis. Addis Ababa University, Addis Ababa, Ethiopia $85 \mathrm{p}$.

[9] ENMA. Ethiopian National Meteorological Agency. (2018) Unpublished raw data of Meteorological stations. Addis Ababa, Ethiopia

[10] FAO. (2010) Global Forest Resource Assessment. Main report, Rome.

[11] FAO. (2015) Global Forest Resource Assessment. How are the world's forest changing? Rome.

[12] Feyissa, A., Soromessa, T. and Argaw, M. (2013) Forest carbon stocks and variations along altitudinal gradients in Egdu Forest: Implications of managing forests for climate change mitigation. Science, Technology and Arts Research Journal, 2 (4), pp. 40-46.

[13] Fisher, R. F. and Binkley, D. (2012) Ecology and Management of Forest Soils. John Willey \& Sons, Inc. New York, USA.

[14] Gibbs, H. K., Brown, S., Niles, J. O. and Foley, J. A. (2007) Monitoring and estimating tropical forest carbon stocks: making REDD a reality. Environmental Research Letters, 2 (4), p. 045023.

[15] Girma, A., Soromessa, T. and Bekele, T. (2014) Forest carbon stocks in woody plants of Mount Zequalla Monastery and its variation along altitudinal gradient: Implication of managing forests for climate change mitigation. Science, Technology and Arts Research Journal, 3 (2), pp. 132-140.

[16] Hairiah, K., Dewi, S., Agus, F., Velarde, S., Ekadinata, A., Rahayu, S. and van Noordwijk, M. (2011) Measuring carbon stocks: across land use systems: a manual. Published in close cooperation with Brawijaya University and ICALRRD (Indonesian Center for Agricultural Land Resources Research and Development). 
[17] IPCC. (2006) Guidelines for National Greenhouse Gas Inventories, Prepared by the National Greenhouse Gas Inventories Programme, Eggleston HS, Buendia L. Publicado por: IGES, Japón.

[18] Lemenih, M. (2015) Secondary Data to Support Establish Forest Reference Emission Level/Forest Reference Level for REDD+ in Ethiopia. Draft final report., Addis Ababa, Ethiopia.

[19] Lemma, B., Kleja, D., B., Olsson, M., and Nilsson, I. (2007) Factors controlling soil organic carbon sequestration under exotic tree plantations: A case study using the $\mathrm{CO}_{2}$ Fix model in southwestern Ethiopia. Forest Ecology and Management 252 (13): 124-131.

[20] Luke. (2018) Evaluation of the Forest Carbon Content in Soil and Litter in Ethiopia. Natural Resources Institute, Finland.

[21] Moges, Y., Eshetu, Z. and Nune, S. (2010) Ethiopian Forest Resources: Current Status and Future Management Options in View of Access to Carbon Finances, Literature Review Prepared for the Ethiopian Climate Research and Networking $(E C R N)$ and the United Nations Development Programme (UNDP).

[22] Moges, Y. and Tenkir, E. (2014) Overview of REDD+ process in Ethiopia. REDD+ Secretariat, Ministry of Environment and Forest.
[23] Oromia Forested Landscape Program (OFLP) Social Assessment (SA). (2017) Addis Ababa.

[24] Pearson, T., Walker, S. and Brown, S. (2005) Sourcebook for land use, land-use change and forestry projects. Winrock International and the BioCarbon Fund of the World Bank, 57.

[25] Pearson, T. R., Brown, S. L. and Birdsey, R. A. (2007) Measurement guidelines for the sequestration of forest carbon. US Department of Agriculture, Forest Service, Northern Research Station.

[26] Rees, R. M., Bingham, I., Baddeley, J., and Watson, C. A. (2005) The role of plants and land management in sequestering soil carbon in temperate arable and grassland ecosystems. Geoderma 128: 130-154.

[27] Schlesinger, W. H. (1990) Evidence from chronosequence studies for a low carbon-storage potential in soil: Letters to Nature. North Carolina 27706.

[28] Woldemariam, T. (2015) GHG Emission Assessment Guideline: Aboveground Biomass. Field Guide for Baseline Survey. Federal Democratic Republic of Ethiopia Ministry of Agriculture, Addis Ababa, Ethiopia, (2).

[29] Woldu, Z., Edward, S., Demissie, A., Bekele, T. and Haase, G. (1999) Forests in the vegetation types of Ethiopia and their status in the geographical context. 